\title{
Discussion on the Application of Financial Accounting Thinking in Equity Investment
}

\author{
Cao Qingzi \\ Zhongnan University of Economics and Law \\ Wuhan 430073 China
}

\begin{abstract}
With the rapid development of China's economy, the number of private equity investment funds has increased greatly in recent years. Equity investment funds help to accelerate the growth of enterprises. However, due to the low entry threshold of equity investment funds, the financial accounting knowledge of a large number of equity investors is not highly professional. This paper expounds the difference between financial accounting thinking and equity inves tment thinking and analyzes the importance of financial accounting knowledge to equity investment business. Finally, this paper analyzes several equity investment cases and illustrates the application of financial accounting knowledge and thinking mode in equity investment business.
\end{abstract}

Keywords-Financial accounting, equity investment, private equity, financial due diligence

I. SIMILARITIES AND DIFFERENCES BETWEEN FINANCIAL ACCOUNTING THINKING AND EQUITY INVESTMENT THINKING

Generally speaking, financial accounting thinking usually focuses on the current situation of enterprises. Financial officers are often only willing to believe in verifiable financial revenues. Due to the requirements of GAAP, financial personnel should abide by the principle of prudence when conducting financial treatment. For example, when we deal with accounts receivable, we often need to prepare for bad debts. Equity investment focuses on the future development of enterprises. The ultimate purpose of equity investment is to obtain greater economic benefits, which can be obtained through profits or dividends, or by other means. Equity managers often focus on the future cash flow rather than the current corporate situation. In particular, VC equity investment funds invest in enterprises at the initial stage of development. These enterprises are small in scale and often have poor financial conditions. Small businesses often come up with innovative business models, and the current financial situation is not indicative of their future growth. Although the two ways of thinking are not exactly the same, there are even contradictions. However, financial accounting thinking is still applicable to equity investment business. In this chapter, we first explain the difference between two kinds of thinking, and then put forward two ways of thinking complementary.

\section{A. Similarities and differences in job functions and objectives of employees}

The job function of financial accounting practitioners is different from that of equity investment managers. This is the fundamental reason for the difference between the two kinds of thinking. The main job responsibilities of financial accounting professionals are to prepare financial statements or conduct external auditing for enterprises. Both functions require financial accounting personnel to give real feedback on the current situation of the enterprise. Therefore, when conducting due diligence or preparing financial statements, financial accounting personnel often need financial evidence to confirm accounting matters. For unconfirmed matters, the accountant usually does not record them or feedback them to the information demander in other ways.

The position of equity manager is different. The job function and purpose of equity managers is to find undervalued companies and make equity investments. Therefore, they tend to pay more attention to the future development and growth of enterprises. Equity managers often need to conduct business model due diligence, financial due diligence and legal due diligence. But the purpose of these due diligence investigations is to determine whether there is a possibility of rapid growth in the future. Equity investments tend to place more emphasis on industry trends and business values. Financial due diligence is often just to determine whether the information provided by the invested enterprise is true or not. The larger an enterprise is, the more important its financial authenticity is to equity investment. For equity investment managers, financial accounting is an essential professional skill.

\section{B. Similarities and differences in the principle of prudence in enterprise evaluation}

Accounting prudence means that in accounting treatment, we should not overestimate assets and earnings, nor underestimate liabilities and losses. The principle of prudence is one of the most important principles in accounting standards. The code of prudence requires that we should be cautious in accounting confirmation, measurement and reporting of transactions or events and should not overestimate capital or earnings, underestimate liabilities or expenses. Because of the principle of prudence, accounting standards require provision for impairment of almost all assets. Moreover, the impairment provisions of fixed assets, intangible assets and other noncurrent assets cannot be reversed once they are calculated and withdrawn, which reflects the principle of prudence. It is said that people who have been engaged in financial accounting for a long time are cautious, which is determined by the nature of their work. The items that enterprises need to calculate and record are very uncertain, so it is difficult to accurately measure. Financial accounting must quantify each record. For 
example, the business personnel can say that this receivable estimate can be recovered, and the financial staff should judge whether the money can be recovered or not, and how likely it is to be recovered. At this time, the information available to the financial staff is limited, and there are many uncertainties. Once the judgment is made, the financial staff shall bear a responsibility. Therefore, it is also a kind of protection to keep necessary caution. It is certainly true that financial staff should be cautious, but excessive caution can also distort the quality of information. The most obvious overuse of prudence is the overuse of historical cost measurement, especially for real estate. Some companies have a lot of the investment real estate, standards also allow use of fair value measurement, but few companies take the initiative to do so, clearly property has risen more than a dozen times, the original cost or purchase price of more than 10 years ago, after depreciation, amortization, net value may be less than one over twenty of the market, seriously has affected the investor to the enterprise value judgment. Equity investments are different. For equity investors, risk is an inevitable cost. Equity investments are more about the future benefits of risk. In the stock market, the stock price of a good company is often higher than the discounted present value of its assets and cash flow.

\section{THE IMPORTANCE OF FINANCIAL ACCOUNTING THINKING TO EQUITY INVESTMENT BUSINESS}

Although there are many differences between the thinking mode of financial accounting and the thinking mode of equity investment, the thinking mode of financial accounting is still very important to equity investment business.

\section{A. Financial accounting thinking can help investment managers to distinguish the real situation of enterprises}

Over the past five years, China has experienced a period of capital mania. More and more entrepreneurs tend to use PPT to show projects to investors. Due to the strong ability to attract investment for high-quality projects, due diligence work of many investment institutions is often not thorough enough. As a result, investment failures often occur. Financial data is a concentrated reflection of the company's operating results and operating efficiency. Three statements -- balance sheet, income statement and cash flow statement -- are formed under the background of accounting standards. There are all kinds of logical relations in the report, between the report and the report, and between the report and the business operation. The analysis of such logical relations is helpful to verify the authenticity of enterprise finance. Equity managers often need to conduct business due diligence on proposed projects. Financial accounting thinking can help investment managers make reasonable judgment on the information provided by enterprises., for example, a high-grade health care products companies, all package is purchased, the package price does not poor, financial data show that in the year of income increase, pay cash is not significantly increase the outer packing suppliers, verify the income false. This is using the fact that the product must be packaged for general inference. A motorcycle production enterprise, the whole motorcycle is composed of more than $\mathrm{N}$ parts, all parts to be purchased. If we want to verify the capacity, the investment manager can follow the changes in the number of key component engines. Therefore, for high-tech manufacturing enterprises, investment managers must have financial accounting thinking. Investment managers should pay attention to details when conducting financial due diligence and not only look at income and profit from financial data.

\section{B. Financial accounting thinking can help investment managers better evaluate enterprises}

Although equity investment caution and financial accounting have obvious differences, equity investment valuation is still based on financial accounting common sense. Good financial accounting thinking is helpful for equity investment managers to clearly judge enterprise value and reasonably evaluate the enterprise. In recent years, there have been some unprofessional investment managers in the market, and when it comes to good projects, valuations tend to be too high. When you want to bargain, the price is often much lower than the common-sense price. These are the investment managers lack financial accounting common sense performance. Such institutions disrupt the market and sometimes drive up share prices, making it difficult for other investors to invest. Sometimes unreasonable bargaining is a waste of business time. Only when the investment manager has the financial accounting thinking can the enterprise be reasonably valued. For example, we should usually use the replacement cost method to estimate the price ceiling when evaluating poorly run health care providers, Banks and other types of businesses. Estimate the price floor based on the current cash flow and assets of the business. Because such enterprises often hold "industry access" qualifications, the value of these qualifications cannot be fully reflected in the financial statements. If the investment manager only values the cash flow and assets of the enterprise, it is obviously not in line with the real value of these enterprises.

\section{Financial accounting thinking can enable investment managers to better compare similar enterprises}

In the equity business, equity managers often choose the industry they want to invest in first and then choose several similar projects in the industry for comparison. In this phase, financial accounting thinking is also very important. Investment managers need to determine whether the industry they invest in is in the growth, maturity or decline stages. Generally speaking, it can correspond to the changes in financial indicators. During the development period, income may increase sharply year by year; during the mature period, it may be relatively stable; and during the recession, it may decline. If financial indicators are against common sense, pay special attention. Micro level, the horizontal comparison is between industry on macroscopic analysis, if the mark is the key financial indicators of the enterprise, such as revenue growth and profitability in the industry is significantly higher than other companies, requires careful analysis. For example, an enterprise claims to be a leader in the industry, but the investment manager observed that its receivables were significantly higher than those of other companies in the same industry. This indicates that the bargaining power of this enterprise to its downstream is lower than that of other enterprises in the same industry. Based on this, investment 
managers should conduct upstream and do wnstream interviews to verify the real situation of the enterprise. Only based on the understanding of financial accounting thinking can investment managers judge the advantages and disadvantages of similar enterprises from the comparison of details.

\section{SPECIFIC CASE -- SIDE VALIDATION OF LASER RED TECHNOLOGY}

In June 2017, we participated in the due diligence investigation of a famous laser manufacturer in China. The company claims to have a unique technology for its lasers. The company's products are more powerful, more stable and enjoy a higher position in the industry. The independent research and development of laser is a very high technology. As an equity investment manager, although I have a certain understanding of the industry, my understanding of technology is difficult to surpass that of experts in the industry. In terms of the overall financial performance of the company, the income and profits of the company are higher than those of other similar enterprises. The academic background of the researchers is also excellent. The financing needs and prices provided by the company are very reasonable. So, on the face of it, this is a very good equity opportunity.

However, we observed from the company's statement that the receivables rate of this enterprise is significantly higher than that of other similar enterprises. At the same time, the company's sales will increase substantially from September to December every year. In general, laser sales do not have a significant periodicity. Based on these phenomena, we suspect that the enterprise is colluding with its downstream dealers. In the first few months of each year when the report needs to be made, the dealer buys a lot from the enterprise, but the two parties only confirm the order and do not carry out the actual transaction. Based on this suspicion, we interviewed the company's downstream customers. Through the interview, we found that although the technology used by this enterprise is very advanced, there are many other products in the market that can replace this technology. We also found that the company's shareholders had his relatives register with a laser distribution company. There are a lot of related transactions between the two companies every year from September to December. While the deals were eventually executed, the company's short - term performance appeared to be inflated. Equity investors tend to value the company based on cash flow, and the price at which the company would have seemed reasonable is now clearly not. Based on these factors, we for real financial data for the reduction of the enterprise, and based on the data of the revaluation, put forward our share purchase, avoiding the financial risk of the amount as much as 100 million RMB.

\section{CONCLUSION}

To sum up, financial accounting thinking while thinking in many ways and equity investment, but it will help the discriminant enterprise investment are the authenticity of information, thus more reasonable value of the enterprise. This can greatly improve the efficiency of equity investment staff. In the future, equity investment funds will become more and more professional. Funds are also increasingly demanding of investment managers. The knowledge and thinking of financial accounting will become the necessary professional skills for employees. This paper expounds the difference between financial accounting thinking and equity investment thinking and analyzes the importance of financial accounting knowledge to equity investment business. Finally, this paper analyzes several equity investment cases and illustrates the application of financial accounting knowledge and thinking mode in equity investment business. This is of great significance to the professional and standardized operation of equity investment enterprises.

\section{REFERENCE}

[1] Shen Haichao. A brief analysis on tax and accounting policies of equity acquisition [J]. Commercial accounting. 2012(20)

[2] Yan Saiyan. Teaching thoughts on accounting treatment of equity-based crowdfunding model [J]. Accounting of Chinese township enterprises. 2017(05)

[3] Li Qi, Peng Yanghui. Correlation between financial restatement and equity incentive -- research based on chi-square test [J]. Friends of accounting. 2014(06)

[4] Chen Chuan. Research on accounting treatment of equity incentive [J]. Finance and economics (academic edition). 2014(11)

[5] Ji Li, Deng Bofu, Mao Hongtao. International convergence of accounting standards, cost of state-owned equity and equity capital -empirical evidence from China's a-share market $[\mathrm{J}]$. Accounting and economic research. 2012(05)

[6] Xu Renfa. Solidifying equity -- the best choice for quantifying collective assets equity [J]. Rural financial accounting. 2004(02)

[7] $\mathrm{Xu}$ Ping. The influence of equity structure on accounting behavior [J]. Journal of Jimei university (philosophy and social science edition). 2002(03)

[8] Tang Qunli. On the impact of equity incentive on enterprise performance -- take Qingdao Haier as an example [J]. Contemporary economy. 2016(23)

[9] Tang Wenjing, Sheng Mingquan. Can equity incentive lead to inefficient investment -- take Luzhou laojiao as an example [J]. Financial and accounting journal. 2016(31)

[10] Zhang Shixing, Zhang Nannan, Liu Yaling. Evolution and improvement of equity investment classification standards [J]. Financial journal. 2015(16) 